\title{
INTERNET SEBAGAI SALAH SATU SUMBER BELAJAR PADA MATA KULIAH INTRODUCTION TO LINGUISTICS
}

\author{
Suhaini M. Saleh dan Titik Sudartinah
}

Email: suhaini@uny.ac.id; titiksudartinah@yahoo.co.id

Fakultas Bahasa dan Seni Universitas Negeri Yogyakarta

Alamat Korepondensi: Perumahan Banteng III/83 Yogyakarta

Perum Gunung Sempu RT02/RW19 No 55 Tamantirto, Kasihan, Bantul, Yogyakarta 55183

\begin{abstract}
This article aims at describing the roles of the internet as a learning resource for students of Introduction to Linguistics at the Study Program of English Language and Literature, Yogyakarta State University. The research was a classroom action research conducted in a class consisting of twenty students in their third semester. In the research, the students were guided in order that they can maximize the use of the internet as an additional learning resource in the subject. The results of the research show that the internet is a useful medium from which students gain a lot of advantages that make them have higher motivation to learn linguistics. Thus, the students achieve higher marks at the end of the course.
\end{abstract}

\section{Keywords}

Internet, Linguistik, Sumber Belajar

\section{Pendahuluan}

Di Program Studi Bahasa dan Sastra Inggris, banyak mahasiswa mengalami kelambatan dan bahkan kesulitan dalam memahami istilah-istilah dasar linguistik dalam berbagai mata kuliah linguistik yang mereka tempuh. Selain terdengar baru di telinga mereka, istilah-istilah tersebut jumlahnya cukup banyak dan buku-buku pegangan yang tersedia tidak selalu memberi definisi yang mudah dimengerti. Rendahnya tingkat pemahaman terhadap istilah-istilah dasar linguistik ini berpangkal antara lain pada materi pembelajaran di kelas yang dianggap sulit sehingga penjelasan dan bimbingan dari dosen tidak mencukupi dan rendahnya motivasi belajar mahasiswa karena anggapan bahwa linguistik itu sulit sehingga mereka cenderung pasif dan tergantung pada penjelasan dosen di kelas.

Dalam memahami sebuah topik misalnya, seorang mahasiswa membutuhkan materi yang bisa diperoleh melalui berbagai sumber, seperti buku, handout, jurnal, ataupun internet. Sumber yang menarik dan mudah dipahami tentu saja banyak menentukan keberhasilan mahasiswa dalam memahami materi yang sedang didalaminya. Sebaliknya, materi yang tidak sesuai akan menghambat pemahaman. Bidang teknologi informasi yang diwakili internet saat ini menyediakan sumber materi yang mudah diakses dosen maupun mahasiswa. Dalam hitungan menit materi-materi tertentu bisa ditemukan dengan mudah, tidak seperti dalam pencarian sebuah buku di sebuah perpustakaan yang besar.

Proses belajar mengajar dalam dunia pendidikan secara umum melibatkan empat buah komponen utama, yaitu murid, guru, lingkungan belajar, dan materi pelajaran. Keempat komponen ini mempengaruhi murid dalam mencapai tujuan belajarnya. Tentunya setiap murid mempunyai berbagai tingkat kemampuan yang berlainan ditinjau dari aspek daya tangkap, pengetahuan yang dimilikinya dalam bidang yang akan dipelajari (prior knowledge), motivasi belajar, ketrampilan belajar (learning skill), tujuan untuk belajar dll. Oleh karena itu, untuk menciptakan pembelajaran yang ideal, beberapa hal mendasar perlu diperhatikan.

Menurut Johnson (2001:24) ada delapan komponen utama dalam sistem pembelajaran yang ideal, yaitu:

Pertama, melakukan hubungan yang bermakna (making meaningful connections). Yaitu, Siswa dapat mengatur diri sendiri sebagai orang yang belajar secara aktif dalam mengembangkan minatnya secara individual, orang yang dapat bekerja sendiri atau bekerja dalam kelompok, dan orang yang dapat belajar sambil berbuat (learning by doing). 
Kedua, melakukan kegiatan-kegiatan yang signifikan (doing significant work). Yaitu, siswa membuat hubungan antara sekolah dan berbagai konteks yang ada dalam kehidupan nyata sebagai pelaku bisnis dan sebagai anggota masyarakat.

Ketiga, belajar yang diatur sendiri (self-regulated learning). Yaitu, siswa melakukan pekerjaan yang signifikan: ada tujuannya, ada urusannya dengan orang lain, ada hubungannya dengan penentuan pilihan, dan ada produknya/hasilnya yang sifatnya nyata.

Keempat, bekerja sama (collaborating). Yaitu, siswa dapat bekerja sama. Guru membantu siswa bekerja secara efektif dalam kelompok, membantu mereka memahami bagaimana mereka saling mempengaruhi dan saling berkomunikasi.

Kelima, berpikir kritis dan kreatif (critical and creative thinking), Yaitu, siswa dapat menggunakan tingkat berpikir yang lebih tinggi secara kritis dan kreatif: dapat menganalisis, membuat sintesis, memecahkan masalah, membuat keputusan, dan menggunakan logika dan bukti-bukti.

Keenam, mengasuh atau memelihara pribadi siswa (nurturing the individual). Yaitu, siswa memelihara pribadinya: mengetahui, memberi perhatian, memiliki harapan-harapan yang tinggi, memotivasi dan memperkuat diri sendiri. Siswa tidak dapat berhasil tanpa dukungan orang dewasa. Siswa menghormati temannya dan juga orang dewasa.

Ketujuh, mencapai standar yang tinggi (reaching high standards). Yaitu, siswa mengenal dan mencapai standar yang tinggi: mengidentifikasi tujuan dan memotivasi siswa untuk mencapainya. Guru memperlihatkan kepada siswa cara mencapai apa yang disebut "excellence".

Kedelapan, menggunakan penilaian otentik (using authentic assessment). Yaitu, siswa menggunakan pengetahuan akademis dalam konteks dunia nyata untuk suatu tujuan yang bermakna. Misalnya, siswa boleh menggambarkan informasi akademis yang telah mereka pelajari dalam pelajaran sains, kesehatan, pendidikan, matematika, dan pelajaran bahasa Inggris dengan mendesain sebuah mobil, merencanakan menu sekolah, atau membuat penyajian perihal emosi manusia.

Dengan semakin canggihnya dunia teknologi, peran komputer sebagai additional resource dalam dunia pendidikan tidak mungkin diabaikan begitu saja. Perkembangan TI yang pesat telah berperan serta dalam menyebabkan bergesernya paradigma belajar. Tabel berikut (sumber: pidato Dirjen Dikmenum pada Dies Natalis UNY tahun 2006) adalah gambaran bagaimana paradigma pembelajaran telah bergeser.

\section{Tabel 1: Changes in Learning}

\begin{tabular}{|l|l|}
\hline \multicolumn{2}{|c|}{ Traditional Learning } \\
\hline 1 & Teacher centered \\
\hline 2 & Single media \\
\hline 3 & Isolated work \\
\hline 4 & Information delivery \\
\hline 5 & Factual, knowledge-based learning \\
\hline \multicolumn{2}{|c|}{ New Learning } \\
\hline 1 & Student centered \\
\hline 2 & Multimedia \\
\hline 3 & Collaborative work \\
\hline 4 & Information exchange \\
\hline 5 & $\begin{array}{l}\text { Critical thinking and informed } \\
\text { decision making }\end{array}$ \\
\hline
\end{tabular}

Tabel di atas menunjukkan bahwa proses belajar saat ini menjadi semakin berorientasi pada kepentingan siswa dengan memanfaatkan multimedia dalam model yang kolaboratif. Guru dituntut untuk memiliki kemampuan berinteraksi dengan siswa secara baik agar proses kolaborasi dalam kegiatan belajar bisa terjadi secara efektif. Guru tidak sekedar menyampaikan informasi melalui proses pembelajaran, namun dari interaksi siswa-guru juga harus bisa terjadi proses tukar-menukar informasi. Dalam hal ini, siswa harus semakin aktif dalam proses belajarnya, harus mampu berpikir kritis dan membuat keputusan.

Untuk menciptakan proses pembelajaran yang demikian, maka perlu dukungan berupa materi dan sumber belajar yang mengikuti perkembangan teknologi. Internet adalah salah satunya. Dibandingkan dengan media pendidikan yang lain, seperti overhead projector, TV, dan film, komputer lebih memungkinkan untuk membuat murid menjadi "aktif" bermain-main dengan informasi. Perangkat lunak dapat dibuat agar interaktif. Hal ini sukar dicapai oleh media lainnya. Hal lain yang menarik, perangkat lunak untuk pendidikan dapat disesuaikan dengan kemampuan dan kebutuhan masing-masing murid. Hal ini memungkinkan murid-murid untuk berkembang sesuai dengan keadaan dan latar belakang kemampuan yang dimiliki. Murid yang memang mampu belajar dengan kecepatan tinggi tidak perlu menunggu rekan lainnya yang memerlukan waktu lebih dalam memahami materi pelajaran. 
Dewasa ini, bukan hanya program-program standard saja yang dipakai untuk membantu pencapaian hasil belajar maksimal, namun juga intenet. Pemanfaatan internet secara signifikan dapat meningkatkan cakupan alat dan sumber belajar siswa. Pemanfaatan internet ini dapat diintegrasikan dalam pembelajaran melalui berbagai cara: internet dapat diposisikan sebagai sumber belajar tambahan untuk melengkapi sesi tatap muka, digunakan bersamaan dengan proses tatap muka, maupun sebagai alternatif pengganti tatap muka.

Meski tidak semua pengajar memanfaatkan internet sebagai sumber pembelajaran, namun siswa kebanyakan menyukai aktivitas web browsing baik dengan tujuan untuk membantu mereka mengerjakan tugas-tugas di kelas, maupun hanya iseng belaka. Mereka harus dibantu untuk mengevaluasi sumber informasi baru ini, karena tidak semua materi di internet berkualitas. Dengan menyeleksi beberapa link web dapat memberi siswa ide mengenai kualitas dan authority materi-materi yang tersedia di internet.

Siswa perlu mengembangkan baik skill browsing mereka maupun kepekaan onlinenya. Artinya, mereka perlu belajar menggunakan ketrampilan mereka dalam memfokuskan pencarian mereka dan memperoleh hasil yang sesuai dengan yang mereka butuhkan, dan memiliki kepekaan dalam membedakan informasi yang akurat dan terpercaya dengan yang sekedar opini belaka. Hal ini akan membantu siswa mengembangkan skill belajar mereka yang relevan untuk melakukan analisis. Tahap berikutnya adalah meminta siswa untuk benar-benar mempelajari materi yang mereka peroleh di web dan mengerjakan tugastugas dengan bantuan sumber belajar tersebut. Jadi, pada dasarnya, keuntungan terbesar yang diperoleh siswa dengan adanya internet adalah ketersediaan sumber belajar yang berlimpah yang dapat membantu mereka memahami dan mengerjakan tugas-tugas di kelas.

Ada beberapa dukungan teoretis dari penggunaan task sebagai basis pengembangan kompetensi siswa. Pertama, dewasa ini ada kecenderungan bahwa pengajaran yang produktif harus berlandaskan fakta yang terjadi di kelas yang sebenarnya, yaitu apa yang dilakukan oleh guru dan siswa (real task). Ini berarti, fakta atau informasi dari siswa atau apa yang terjadi di kelas digunakan untuk merencanakan, menerapkan, dan menilai program pengajaran yang dilaksanakan (Nunan, 1993: 19). Variabel task secara signifikan mempengaruhi performansi siswa dalam belajar. Jiwa dari task adalah interaksi.
Landasan teoritis berikutnya, seperti yang sudah sedikit diungkap di atas, melalui task, PBM diharapkan lebih 'hidup'. Dengan pemberian task mahasiswa diharapkan lebih mandiri dan siap untuk berinteraksi di kelas. Oleh karena itu, penelitian ini memfokuskan pada pemberian task kepada mahasiswa dengan memanfaatkan internet untuk menciptakan pembelajaran yang ideal dengan mengasah kemampuan siswa untuk melakukan delapan komponen penentu pembelajaran seperti yang telah disebutkan di atas.

\section{Metode}

Penelitian ini bertujuan untuk mendeskripsikan peran internet sebagai sumber belajar untuk meningkatkan motivasi mahasiswa dan meningkatkan pemahaman terhadap konsepkonsep dasar linguistik mahasiswa dalam mata kuliah Introduction to Linguistics.

Penelitian ini merupakan Classroom Action Research (CAR) atau dikenal juga dengan istilah Penelitian Tindakan Kelas (PTK). Tentang penelitian tindakan, McNiff (2002: 16) menyatakan bahwa penelitian ini merupakan sebuah tipe penelitian yang relatif baru. Penelitian tindakan merupakan aplikasi penemuan fakta untuk pemecahan masalah secara nyata dalam sebuah situasi sosial dengan cara melibatkan kolaborator dan kerjasama antara peneliti, praktisi dan orang-orang lain di sebuah lingkungan. Penelitian tindakan bisa diterapkan di kelas, sekolah, kantor, institusi dan sebagainya.

Menurut Burns (1999: 30) penelitian tindakan kelas melibatkan pembelajaran melalui tindakan dan refleksi. Hal ini mencakup pengumpulan data, refleksi pada tindakan yang dilakukan berdasarkan data tersebut, mengumpulkan buktibukti dan membuat kesimpulan berdasarkan bukti-bukti yang sudah divalidasi.

Berdasarkan pemahaman tentang makna dan hakikat penelitian tindakan, seorang pengajar bisa menjadi peneliti yang secara kolaboratif melakukan penelitian tindakan kelas untuk mengubah kondisi PBM di kelasnya. Aspek-aspek PBM yang menjadi objek peningkatan bisa mencakup pendekatan-pendekatan, metode, teknik, materi, kurikulum, manajemen kelas, sistem evaluasi, dan setting belajar mengajarnya. Melalui tindakan-tindakan nyata di kelas dan melalui refleksi-refleksi yang dilakukan untuk melihat kekurangan-kekurangan dan peningkatan-peningkatan yang dihasilkan, peneliti berupaya untuk menciptakan situasi dan kondisi yang lebih baik dari sebelumnya. 
Ada 4 karakteristik penelitian tindakan. 1) penelitian tindakan bersifat konstektual, berskala kecil dan bersifat lokal karena penelitian ini mengidentifikasi dan memecahkan masalah dalam situasi yang spesifik, 2) jenis penelitin ini dimaksudkan untuk mengubah dan memperbaiki sebuah keadaan; 3) penelitian ini merupakan kerja kolaboratif antara kelompok-kelompok teman sejawat, praktisi dan peneliti; 4) penelitian didasarkan pada pengumpulan informasi atau data untuk mengevaluasi perubahan yang dilakukan. Jadi, penelitian tindakan akan berfungsi optimal bila ada kerjasama di antara semua pihak yang terkait dengan situasi yang ingin ditingkatkan.

Berdasarkan hal ini, peneliti melakukan penelitian tindakan kelas kolaboratif dengan melibatkan seorang dosen pengajar yang biasa mengajar di beberapa kelas paralel Introduction to Linguistics, dua orang kolaborator yang mengajar di kelas-kelas linguistik dan para mahasiswa di kelas yang menjadi subjek penelitian, yaitu program studi Bahasa dan Sastra Inggris semester III peserta mata kuliah Introduction to Linguistics di Prodi Bahasa dan Sastra Inggris FBS UNY (1 kelas, terdiri dari sekitar 20 mahasiswa).

\section{Diskusi dan Temuan}

Banyak mahasiswa tidak bisa memahami dengan cepat ketika mengikuti beberapa mata kuliah linguistik, misalnya Phonetics and Phonology, Semantics, Sociolinguistics dan Psycholinguistics, sudah menjadi perbincangan yang tidak asing lagi. Para pengajar tersebut merasa bahwa bahkan konsep-konsep yang mendasar pun tidak dikuasai oleh banyak mahasiswa walaupun sebelumnya mereka sudah lulus mata kuliah pengantar Introduction to Linguistics yang merupakan prasyarat mata kuliah-mata kuliah tersebut. Padahal, mata kuliah pengantar tersebut didesain untuk memberi bekal dasar bagi mahasiswa agar mereka tidak asing lagi dengan konsep-konsep penting yang bisa mempermudah mereka untuk mengikuti kuliahkuliah linguistik lain yang relevan.

Peneliti dan kolaborator, yang sama-sama mengampu mata kuliah Introduction to Linguistics di kelas paralel, mencoba untuk menelaah beberapa masalah yang menjadi penghambat bagi mahasiswa untuk bisa memahami materi seperti yang diharapkan. Ada yang menyatakan bahwa selama ini metode lecturing hampir selalu digunakan karena sumber materi masih terlalu sulit dibaca oleh peserta yang masih semester III. Dosen lain menyatakan bahwa walaupun sudah diminta untuk membaca materi sebelum kuliah berlangsung, tetap saja banyak mahasiswa yang tidak mempersiapkan diri. Oleh karenanya, dosen tersebut membantu mahasiswa dengan menampilkan ringkasan dalam bentuk power point.

Menindaklanjuti pembicaraan tentang kekurangoptimalan hasil perkuliahan Introduction to Linguistics, diputuskan untuk melakukan survei awal tentang pendapat mahasiswa berkenaan dengan mata kuliah tersebut. Berdasarkan hasil penyebaran kuesioner secara acak kepada 25 mahasiswa yang pernah mengambil mata kuliah Introduction to Linguistics dengan 3 dosen yang berbeda di tahun 2004, 2005, 2006 dan 2007, diperoleh informasi yang berkaitan dengan pengajaran mata kuliah ini, misalnya mengenai ada tidaknya silabi, topik apa saja yang mereka dapatkan dari mata kuliah ini, buku bacaan dan referensi, metode yang biasa diterapkan oleh dosen, persiapan dan keaktifan mereka di kelas, dan lain-lain yang tercakup dalam 15 butir pertanyaan.

Berikut ini adalah hasil survei yang menunjukkan kelemahan-kelemahan umum yang biasa terjadi di kelas Introduction to Linguistics. Pertama, kemampuan mahasiswa untuk membaca buku referensi masih lemah. Kedua, buku-buku referensi yang ada kurang merangsang minat mahasiswa untuk membaca. Ketiga, sebagian besar mahasiswa tergantung pada dosen. Keempat, banyak mahasiswa tidak melakukan persiapan materi sebelum kuliah dimulai. Kelima, mahasiswa cenderung pasif di dalam kelas.

Berkaitan dengan hasil survei tersebut, maka beberapa langkah dilakukan dalam tiap siklus penelitian. Kemudian, peneliti dan dosen kolaborator melakukan refleksi untuk melihat tingkat keberhasilan tindakan yang dilakukan. Dari pelaksanaan tindakan-tindakan yang dilakukan bisa disimpulkan bahwa ada beberapa tindakan yang berhasil memberi efek positif seperti yang diharapkan, yaitu:

Pertama, pemberian nama-nama website linguistik. Langkah ini dilakukan dengan tujuan memberikan panduan dan contoh pada mahasiswa mengenai beberapa website linguistik yang terpercaya serta bagaimana mengasah kepekaan online mereka untuk mencari berbagai website linguistik lain yang cukup kredibel. Beberapa website yang diberikan oleh dosen ternyata memang dikunjungi oleh mahasiswa dan dipakai sebagai acuan tambahan bagi mahasiswa dalam menulis paper.

Kedua, penggunaan internet sebagai sumber berbagai materi penunjang perkuliahan. 
Mahasiswa dapat mengakses materi yang tersedia online yang mereka butuhkan untuk menunjang perkuliahan di kelas. Ternyata langkah ini merupakan salah satu cara yang berguna untuk meningkatkan motivasi siswa dalam mempelajari konsep-konsep dasar linguistik, terbukti dari antusiasme mereka yang cukup tinggi ketika menemukan berbagai istilah yang baru mereka dengar dan mendiskusikannya di kelas.

Ketiga, pembuatan materi secara berkelompok dengan memanfaatkan internet. Walaupun hasilnya belum memuaskan, paling tidak mahasiswa (terutama presenter) sudah mencoba untuk belajar sendiri. Semua paper telah diselesaikan dan dibagikan kepada semua anggota kelas beberapa hari sebelum presentasi sehingga semua dapat berpartisipasi di kelas ketika topik tersebut dibahas.

Keempat, penugasan presentasi secara berkelompok. Presentasi berkelompok bisa terlaksana tanpa menimbulkan kecemasan yang berlebihan pada diri presenter. Presentasi berkelompok ini juga berdampak pada pembagian kerja antar anggota - salah satu mahasiswa berbicara dan yang lain mengoperasikan media walaupun sebetulnya keduanya diharapkan berbicara.

Kelima, pengunggahan (uploading) materi presentasi mahasiswa ke situs e-learning UNY (http://www.besmart.uny.ac.id). Pada langkah ini, materi presentasi mahasiswa yang telah mengalami beberapa tahap revisi diunggah ke website e-learning UNY dengan tujuan agar dapat dimanfaatkan oleh kalangan yang lebih luas lagi, tidak terbatas hanya mahasiswa kelas yang dijadikan setting penelitian.

Peningkatan pemahaman mahasiswa dalam kelas Introduction to Linguistics bisa dipaparkan sebagai berikut:

Pertama, dari 20 mahasiswa peserta, 18 mahasiswa (90\%) lulus dengan range nilai antara 65,99 (B-) dan 91,38 (A). Mahasiswa yang tidak lulus $2(10 \%)$ mendapatkan skor 45,75 dan 55,41. Catatan menunjukkan bahwa kedua mahasiswa ini sering tidak hadir dalam pertemuan di kelas dan merupakan repeaters. Nilai merupakan gabungan antara nilai kehadiran, partisipasi kelas, paper, kuis, ujian mid-semester dan ujian akhir.

Kedua, berdasarkan komentar yang diberikan oleh mahasiswa yang menjadi subjek penelitian, kelas ini memiliki kesan dan dampak positif dalam meningkatkan pengetahuan mereka tentang linguistics. Ada 12 mahasiswa (60\%) menyatakan bahwa kelas ini membuat mereka menjadi pembelajar yang mandiri, 11 mahasiswa (55\%) mengatakan terkesan dengan metode pembelajarannya, 10 mahasiswa $(50 \%)$ merasa bahwa materi buatan mereka bermanfaat dan 6 mahasiswa (30\%) mengatakan kuis memiliki dampak yang positif.

\section{Penutup}

Tidak selalu tersedianya definisi konsep-konsep dasar linguistik yang dirasa mudah oleh mahasiswa melalui buku referensi yang ada menyebabkan perlunya solusi alternatif lain, antara lain adalah dengan memanfaatkan teknologi informasi berupa internet. Internet telah banyak digunakan baik oleh mahasiswa maupun dosen untuk mendapatkan informasi yang berkaitan dengan mata kuliah. Selain buku acuan, internet dijadikan alternatif sumber pembelajaran yang sangat berguna sekaligus menarik.

Dengan mengakses internet dan membuka banyak situs linguistik, mahasiswa akan menemukan dan menjadi akrab dengan banyak istilah linguistik beserta dengan penjelasannya. Semakin sering mereka menemukan istilahistilah tertentu maka istilah-istilah itu semakin dianggap penting dan sering digunakan dalam linguistik. Pencatatan istilah-istilah yang ditemukan dan merumuskan kembali definisinya dengan kata-kata mahasiswa sendiri tentu akan sangat membantu mahasiswa dalam memahami istilah-istilah tersebut. Proses sharing yang dilakukan di kelas ataupun melalui dunia maya mampu menambah dampak positif pada meningkatnya pemahaman mahasiswa terhadap konsep-konsep dasar linguistik yang harus dikuasai pada mata kuliah tersebut.

\section{DAFTAR PUST AKA}

Aitchison, Jean. 2003. Linguistics. London: Hodder Headline.

Burns, Anne. 1999. Collaborative Action Research for English Language Teachers. Cambridge: Cambridge University Press. 
Crystal, David. 1992. The Cambridge Encyclopedia of Language. Cambridge: Cambridge University Press.

Johnson, Elaine B. 2001. Contextual Teaching and Learning: What It Is and Why It's Here to Stay. Thousand Oaks, CA: SAGE Publications.

Jones, Daniel. 1992. The Pronunciation of English. Cambridge: Cambridge University Press.

Kemmis, S. \& Mc Taggart, R. 1990. The Action Reasearch Planner. 3rd. Deakin: Deakin University Press.

Madya, S. 2001. Penelitian Tindakan dalam Pendidikan dan Pengajaran. Makalah Seminar. Karangmalang: UNY.

McNiff, J and J. Whitehead. 2002. Action Research: Principles and Practice. 2nd ed. London: Routledge Falmer.

Nunan, David. 1993. "Task-based Syllabus Design: Selecting, Grading and Sequencing Tasks." dalam G. Crookes dan S. Gass (eds). Task and Language Learning: Integrating Theory and Practice. Clevedon: Multilingual Matters.

O’Grady, William et al. 1996. Contemporary Linguistics: an Introduction. Harlow: Pearson Education.

Trudgill, Peter. 1983. Sociolinguistics: An Introduction to Language and Society. London: Penguin.

Widdowson, H.G. 1996. Linguistics. Oxford: Oxford Univ Press. 